\title{
FACTORS OF CHOICE OF PRIVATE MEDICAL SERVICES IN POLAND
}

\author{
Julianna STASICKA ${ }^{1 *}$, Igor SZYMAŃSKI² \\ ${ }^{1}$ Poznan University of Economics and Business, Poland; julianna.stasicka@phd.ue.poznan.pl, \\ ORCID: 0000-0003-1656-5877 \\ ${ }^{2}$ Poznan University of Medical Sciences, Poland; 78905@student.ump.edu.pl, ORCID: 0000-0002-4598-5224 \\ * Correspondence author
}

Purpose: The main purpose of this article was to explore main factors of choice of private medical services by Polish patients.

Design/methodology/approach: In the theoretical part of the article, the current situation in health care sector in Poland was discussed. Also, based on the literature authors introduced their own classification of factors of choice of private medical services. The empirical research was conducted in August 2021. Finally, 122 participants were included in a research sample.

Findings: The biggest number of respondents indicated the availability of appointments as the most fundamental aspect. Also, the study revealed other factors, especially choosing a particular physician, previous positive experiences, the transparency of treatment and the quality of care as important for patient's choice.

Research limitations/implications: Research was limited to the private sector which results from the fact that its share on the market grows and is increasingly popular among foreigners. It is worth considering to further deepen the research including studying factors in public health care sector to compare them or to expand the research group to a larger population. Due to technical development forced by recent epidemiological situation of SARS-CoV-2019 pandemic, also it is worth to include telemedicine into future studies.

Practical implications: Private sector operates on the laws of economy which allow the implication of research findings to gain competitive advantage in areas which are most important for patients treated as customers. Outcomes of this article have practical implications for private medical entities. They could enhance operation areas which were chosen by patients. Social implications: Polish health care sector is one of the national economy segments. Providing access to medical services for citizens is one of important government's activities. In case of insufficient access, private sector may be able to support public health care system. Originality/value: It is crucial to conduct such a research among Polish patients because these factors may differ due to a particular country and its specific determinants like political solutions, culture, functioning of health care system, types of medical insurance and other specific conditions. Moreover, in the theoretical part of the article, authors built their own classification of factors of choice of private medical services.

Keywords: private health care, patient's choice. 


\section{Introduction}

Health status correlates with people participation in labor market and work productivity due to influence on human performance. Moreover, the state of health of society is connected with economic development of the country, stimulating economic growth (Korporowicz, 2012). Therefore, public spending on health care is an important investment of the state. The system of financing health care should enable citizens to use all necessary health services. In addition, a sufficient level of funding is necessary to protect citizens from personal costs of health services occurring in case of illness and vocational absence (Zgliczynski, 2018). The structure and level of health care financing is one of the main problems in Polish health care sector. Share of GDP is one of the lowest among developed countries (Bukowski and Pogorzelczyk, 2019). According to data provided by the Organization for Economic Co-operation and Development (OECD), Poland allocates concomitantly 7,2\% of GDP on health sector, including both, public and private. Exactly 5,2\% of GDP on public and 2,0\% of GDP on private sector respectively (OECD, 2021). Despite the improvement of the indicator over the years, still, in Poland the share of GDP on health care sector is one of the lowest among OECD countries. Because of that, there are many problems in Polish health care system functioning and a successful delivery of services. One of the main problems of Polish health care sector are modest human, material and financial resources. Insufficient public funding generates problems with ensuring availability of guaranteed healthcare entitlements, therefore private sector popularizes. The private sector ensures effective access to medical services without queues which is a crucial drawback of the public sector (Bukowski and Pogorzelczyk, 2019).

Health systems in all countries face many different challenges such as increasing demand for quality of care and safety, ensuring universal access to health services and the rising costs of health services. For managers of health care entities, analytical observation and understanding of these phenomena is crucial to survive in turbulent environment (Jędrzejczyk, Wojtecka and Zarzeczna-Baran, 2017). Referring to an increasing demand for medical services and low spending on the public sector, the development of private health care sector succeeds in establishing new multidisciplinary hospitals and clinics. In 2017, the value of private health care sector in Poland was estimated at EUR 8 billion (Rutkowski, 2019). Moreover, the combination of great quality of medical services and relatively low costs make Poland attractive to foreign patients. Their savings can reach up to $80 \%$ in comparison to costs in Western Europe. More and more Polish medical entities are looking for the opportunity to gain share of the international market (Ministry of Foreign Affairs, 2019).

Private health care entities need to recognize which criteria mainly influence patients' choice in order to encourage them to use their services and retain them in long-term relationships. Various factors of patient's choice for the private services differ depending on country due to distinct healthcare systems and types of insurance. Also, particular national characteristics such 
as culture or administrative settings are important and make comparisons between countries difficult (Malik and Sharma, 2017). As a result, there is an imperative need to study this matter in Poland. As it is known, the supply of health care services does not cover in a linear relationship with its demand, therefore there is the necessity of increasing the effectiveness of health care system. Identifying the factors of private services choice allows establishing of competitive advantage of private sector which operates based on economy laws and leads to profit achievement (Can and Isin, 2018). Value of private sector is predicted to grow at faster pace. It especially concerns rehabilitative and curative care. Moreover, steep growth is expected to continue due to private sector development for middle and upper-class. Also, it is enforced by strong dissatisfaction with public treatment (Bukowski and Pogorzelczyk, 2019).

In Poland, medical entities face with rapidly changing conditions of operation due to environment pressure. The increase in awareness and expectations of customers with the simultaneous increase in competition and constant pursuit to increase economic efficiency and the simultaneous economic effects are one of the challenges. The requirements and expectations are constantly growing, and organizations have to improve the quality of the services they offer to adapt changes and survive (Gołębiowski, Wojnarowska and Jędrzejczyk, 2017).

\section{Theoretical background}

Service sector has a great contribution to national GDP. The development of the health care sector constitutes the same importance as the development of any other sector in economy, even if it is not linked to public funds transfer only. Fiscal burdens offset benefits. In Poland, the source of medical services funding can be distinguished into a public and private area (Pietryka, 2018). Efficient operation of the healthcare sector largely depends on the way it is financed, and thus the choice of an appropriate model of the health care system. The proper fit of a specific healthcare model is determined by individual factors of economic development and the adpoted health policy (Wielicka, 2014). The role of the main public payer in Poland is fulfilled by the National Health Fund (NFZ). Especially, the scope of its activities is financing of health care services from public funds to eligible people (Bromber, 2017). Compulsory health insurance based on the Constitution of Poland guarantees equal access to health services for every Polish citizen. However, individual payments accounted for a sustainable part of household expenses (around 22,6\% as of 2016). More than 65\% of expenses were distributed for medical goods like medications (Bukowski and Pogorzelczyk, 2019).

Private funding can be divided into two models. The first one is a direct form of payments which means the usage of commercial services. The second form is cost-sharing of benefits in which a patient has health insurance and participates in costs of provided services (Pietryka, 2018). 
According to Guy (2019), patients decide to pay for private medical services in order to receive the treatment not available in public insurance in the way they need or expect. Although patients using private health care services are sometimes directed to public entities in occurrence of clinical situations, e.g. emergency situations, they predominantly do not select the place of private treatment randomly. Nowadays patients are conscious to choose proper place fulfilling their needs. Earlier their decisions mostly depended on their family, friends or referring doctor due to lack of own knowledge. With reference to rising awareness, higher literacy rate, higher income and broader access to media patient demand great quality of services and even a special personal approach. These days, patients carefully select services before they decide to make an appointment (Malik and Sharma, 2017). Based on literature study of Garedew, Woldie and Walle (2019), Can and Isin (2018) and also Malik and Shrama (2017), authors of this article decided to order factors of private medical services choice in categories concerning main dimensions. Results are shown in the Table 1.

Table 1.

Categories of factors of choice of private medical services - literature study

\begin{tabular}{|l|l|}
\hline \multicolumn{2}{|c|}{ Factors of choice of private medical services } \\
\hline Factor & Specification \\
\hline Recommendation & $\begin{array}{l}\text { Family/friend/other patient/media or internet recommendation of private facility, } \\
\text { physician recommendation of certain facility }\end{array}$ \\
\hline Good own experience & Prior own experience with private facility \\
\hline Interpersonal factors & Politeness of stuff, individual approach \\
\cline { 2 - 2 } Choice of specific practitioner working in the facility, personal relation & Informal acquaintances with any personnel member \\
\hline Transparency of treatment & $\begin{array}{l}\text { Explanation of procedures, transparent and available information, involvement in } \\
\text { decision making }\end{array}$ \\
\hline Facility's brand image & $\begin{array}{l}\text { Reputation of the facility and its management, fame of doctors, insurance } \\
\text { provider, opinion about the staff }\end{array}$ \\
\hline Accessibility to treatment & $\begin{array}{l}\text { Scheduling of appointments, waiting time, continuous care, lack of delays, } \\
\text { hospitalization length }\end{array}$ \\
\hline Quality of care and staff & $\begin{array}{l}\text { Time per patient, safety measures, privacy of examination, avoidance of } \\
\text { unnecessary suffering/stress/inconveniences, personnel qualifications and } \\
\text { experience, training, surgical work volume }\end{array}$ \\
\hline Location and transport & $\begin{array}{l}\text { Proximity to residence, ease of transportation, parking availability, nearby off- } \\
\text { facility services }\end{array}$ \\
\hline $\begin{array}{l}\text { Resources and technical } \\
\text { facility }\end{array}$ & $\begin{array}{l}\text { Latest technology and techniques, accessibility to procedures and diagnostics, } \\
\text { multi-specialty services, sufficient number of personnel }\end{array}$ \\
\hline Sanitary conditions & $\begin{array}{l}\text { Building and infrastructure condition, cleanliness and hygiene, non-intrusive } \\
\text { surrounding environment }\end{array}$ \\
\hline
\end{tabular}

Source: own elaboration based on "Choice of Healthcare Providing Facility and Associated Factors among Government Employees in Nekemte Town, Western Part of Ethiopia. Compliance of Nurses to National Nursing Process Guideline in Tercha General Hospital, Southern Ethiopia 2018: Case Study" by Garedew, Woldie and Walle (2019), "Which criteria determine the winner for patient?" by Can and Isin (2018), "Determinants of Patients' Choice of Healthcare provider - a Study of Selected Private Hospitals in Delhi - NCR" by Malik and Shrama, (2017). 


\section{Description of research method}

Taking into consideration problems with access to public health care system's services and increasing popularity of private sector, the following research question was proposed: What are the most important reasons of private medical services choice by patients in Poland? In reference to the research question, main purpose of the study was posted, which is the identification of key incentives to choose private health services. The empirical research was done in August 2021 and involved Polish citizens which used private medical services in the last 5 years, regardless of the method of payment. Limiting the research to the private sector results from its dynamically growing share on the market. Surveys were conducted using Google web forms. The survey would ensure full anonymity of respondents to gather reliable data. The questionnaires were shared and made available to respondents for one week. After this period, a proper amount of surveys was gathered and the access to the survey questioner was closed.

The first question in the survey concerned declaration of attendance in private health services and allowed to select proper respondents. Questionnaires with required data were included in the research sample. A total of 122 answers of participants were chosen to research analysis. Table 2 presents basic information about the respondents.

\section{Table 2.}

Basic information concerning respondents

\begin{tabular}{|l|l|l|}
\hline \multicolumn{2}{|c|}{ Information about respondents } & Share \\
\hline Feature & Number & \\
\hline Gender: & 81 & $66 \%$ \\
Female & 41 & $44 \%$ \\
Male & & \\
\hline Place of residence: & 37 & $30 \%$ \\
village & 46 & $38 \%$ \\
town with 100 000 inhabitants to 2 500 000 inhabitants & 39 & $32 \%$ \\
city with more than 250 000 & & \\
\hline Age (in years): & 40 & $33 \%$ \\
18-25 & 33 & $27 \%$ \\
$26-35$ & 28 & $23 \%$ \\
$36-50$ & 21 & $17 \%$ \\
up to 50 & & \\
\hline
\end{tabular}

Source: own elaboration based on research results.

The results obtained in the study are presented in the following section of the article. In the last part of the study conclusions are selected and main recommendations proposed. 


\section{Results of empirical study}

The first question in the survey questionnaire concerned the fact of using private medical services, therefore, participants were asked if they had used private medical services in the last 5 years. The purpose of the question was to select the research sample. The 5 year period was chosen due to contemporary situation of global SARS-CoV-2019 pandemic to alleviate its influence on the study. At this stage, people who did not meet the criteria consistent with the adopted research objective were rejected. The results are shown in the Figure 1.

Have you used private medical services in Poland in the last 5 years?

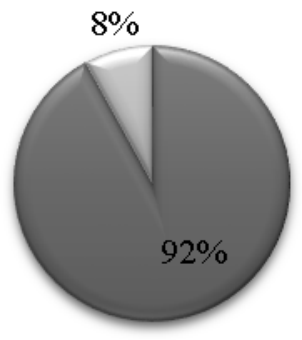

Figure 1. Use of private medical services in Poland over the last 5 years. Source: own study.

The vast majority of respondents have used private health services in the last five years (92\%). People who answered in the negative gave the following reasons: do not have such a need due to lack of serious health problems; possibility to wait for an appointment financed by the National Health Fund; private services are too expensive in comparison with the change in waiting time; not affordable due to personal financial reasons. One person indicated that he does not live in Poland.

The second question referred to the form of financing the visits (Figure 2). Suggested answers included private insurances and self-funding.

How have your private visits to specialists been mainly financed in the last $\mathbf{5}$ years?

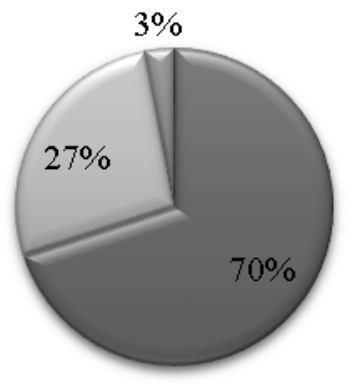

$\square$ paid from own pocket

$\square$ private medical ensurance paid or co-paid by employer

$\square$ individually purchased medical insurance

Figure 2. Main forms of financing the use of private medical services. Source: own study.

The majority of people paid for the access to private health care from their own pocket $(70 \%)$. Taking into account the place of residence, highest percentage of self-funding occurred in group of respondents living in rural areas (80\%), than in the towns up to 250000 inhabitants (70\%) and on the last position in cities with more than 250000 (62\%). Next following share on 
the figure was private medical insurance paid or co-paid by employer (27\%). When the place of residence is taken into account, the relationship is inverse to paying from own pocket because the biggest contribution from employers who funded medical insurance occurred in cities with more than 250000 inhabitants (36\%), then in towns with up to 250000 inhabitants $(30 \%)$, with the smallest share in rural areas (14\%). Altogether, only a small number of people $(3 \%)$ have individually purchased medical insurance.

Another question closely related to the aim of the study concerned the relevance of the indicated factors towards the decision to use private medical services in Poland. The earlier described 12 categories were indicated and respondents were asked to rate the importance of each factor in a 5-grade scale. The factors included:

- recommendations obtained (from family, friends, internet portals containing opinions about physicians),

- own positive experience with private medical care,

- courtesy of staff and individual approach,

- choosing a particular physician,

- the conditions of the facility (cleanliness, infrastructure, ease of access for people with disabilities),

- modern equipment and up to date treatment techniques,

- location and transport (distance from home, parking availability),

- quality (time per patient, avoidance of unnecessary stress, low complication rates),

- availability of appointments (waiting time, length of treatment, no delays),

- reputation of the medical institution (opinion about the institution or doctor),

- transparency of treatment (clear explanation of the problem, participation in making decisions about treatment),

- informal acquaintances with a staff member working at particular facility.

Each respondent was asked if a specific factor is either very important, important, rather not important, not important or has no effect on their decision to use private health care services. The results of answers are shown in Figure 4 and Figure 5. Answers marked as "I don't know" were excluded from the charts due to no provided informational value. 


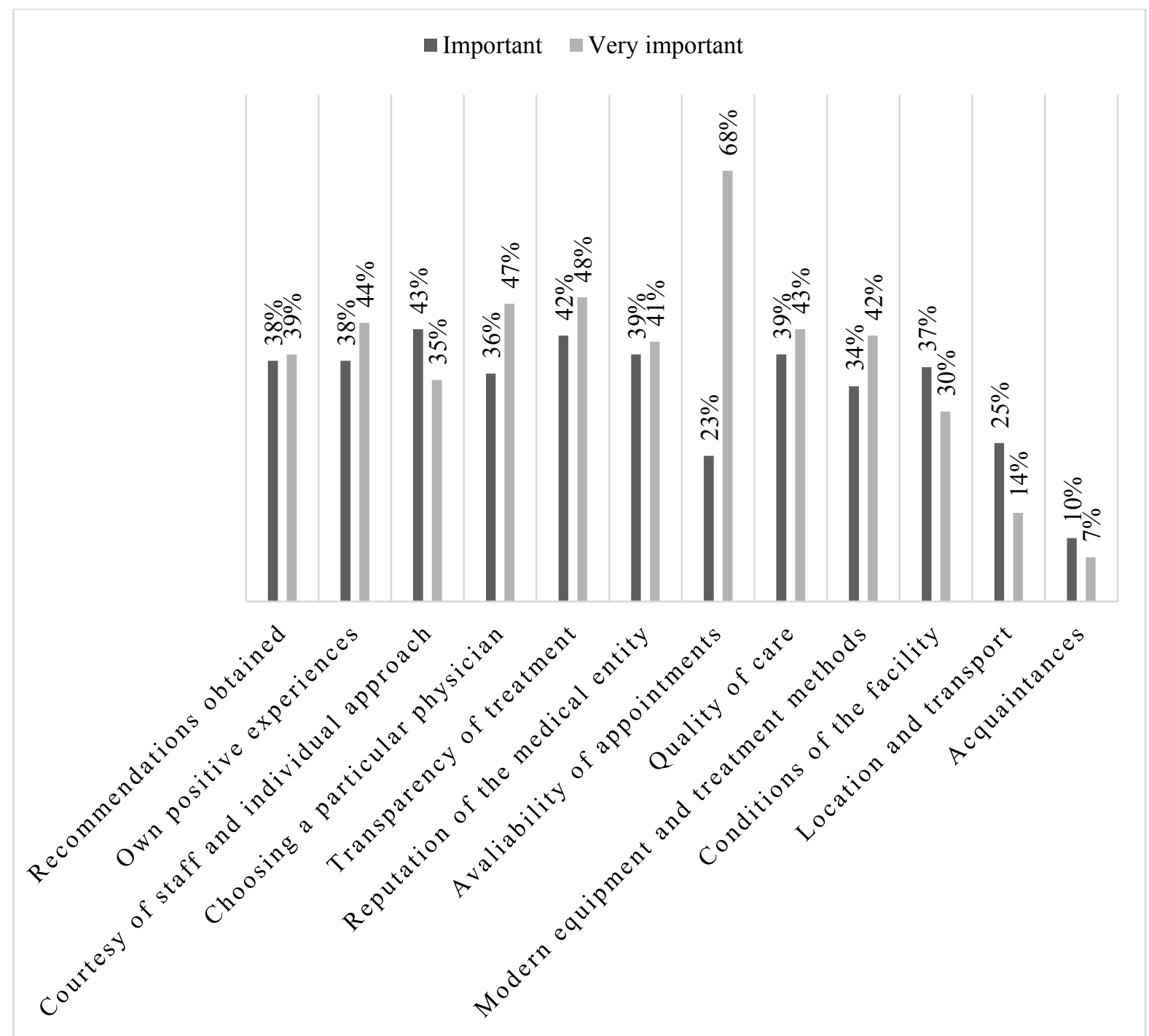

Figure 3. The most significant factors of private medical services choice. Source: own study. 


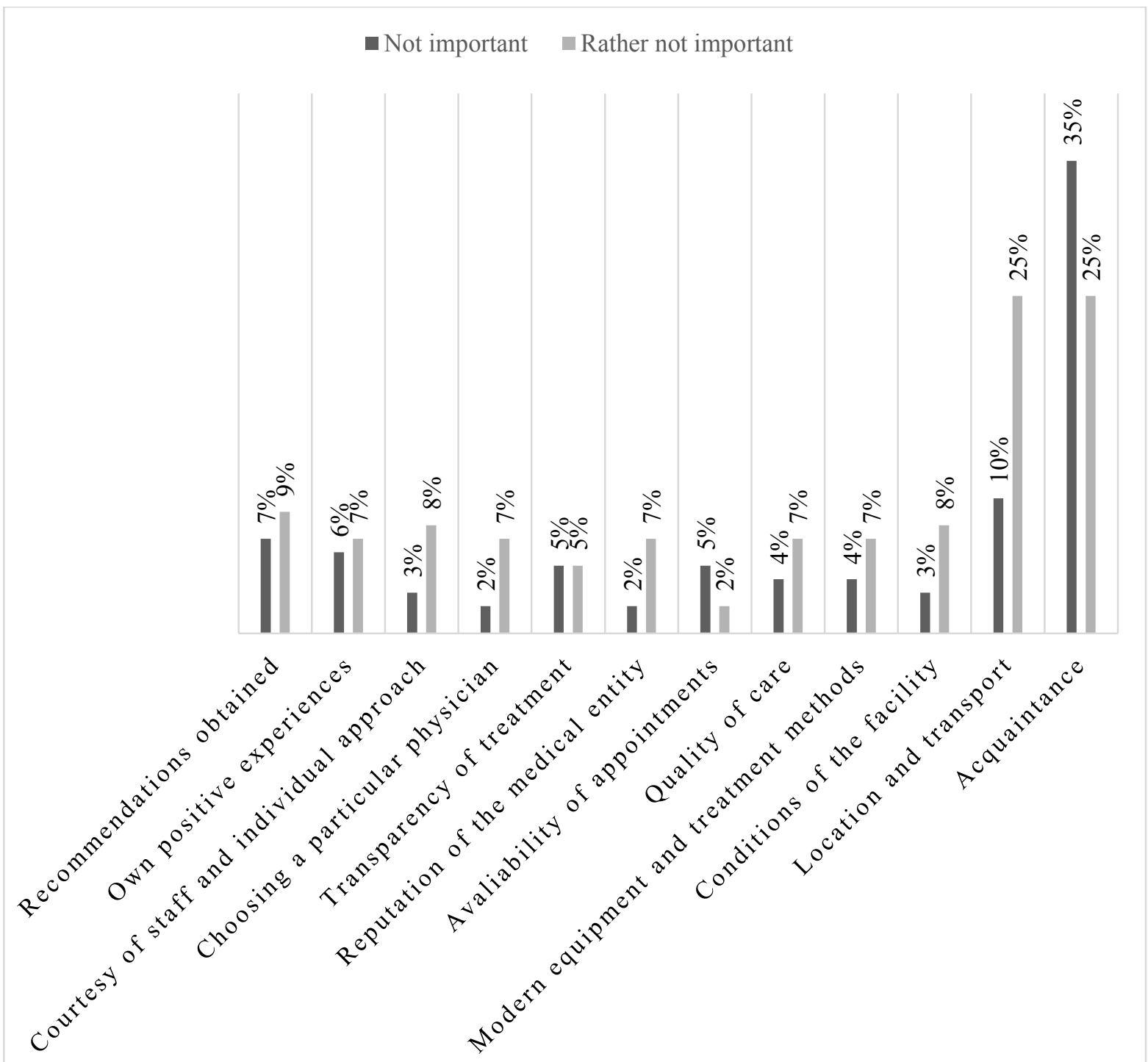

Figure 4. The least significant factors of private medical services choice. Source: own study.

Most of the studied factors (10 out of 12) were indicated as important or very important by the majority of respondents. The study revealed that the most significant factor for participation in private health care services is the availability of appointments with almost $68 \%$ of respondents finding it very important. Only two factors, location and transportation and informal acquaintances proved to be perceived very differently by the respondents. Informal acquaintances factor was chosen by the most respondents as not important (35\%) and by least respondents as important $(10 \%)$ or very important $(7 \%)$. Location and transportation were chosen approximate by the same number of respondents to be important or very important and of low or no importance.

Next question leaded to finding the most frequently visited specialist by research participants over the past 5 years. Because of differences in response distribution resulting from distinct medical needs, in this part of article the research sample is additionally divided into two groups depending on sexes. Results of answers are shown in the Figure 5 and Figure 6. 


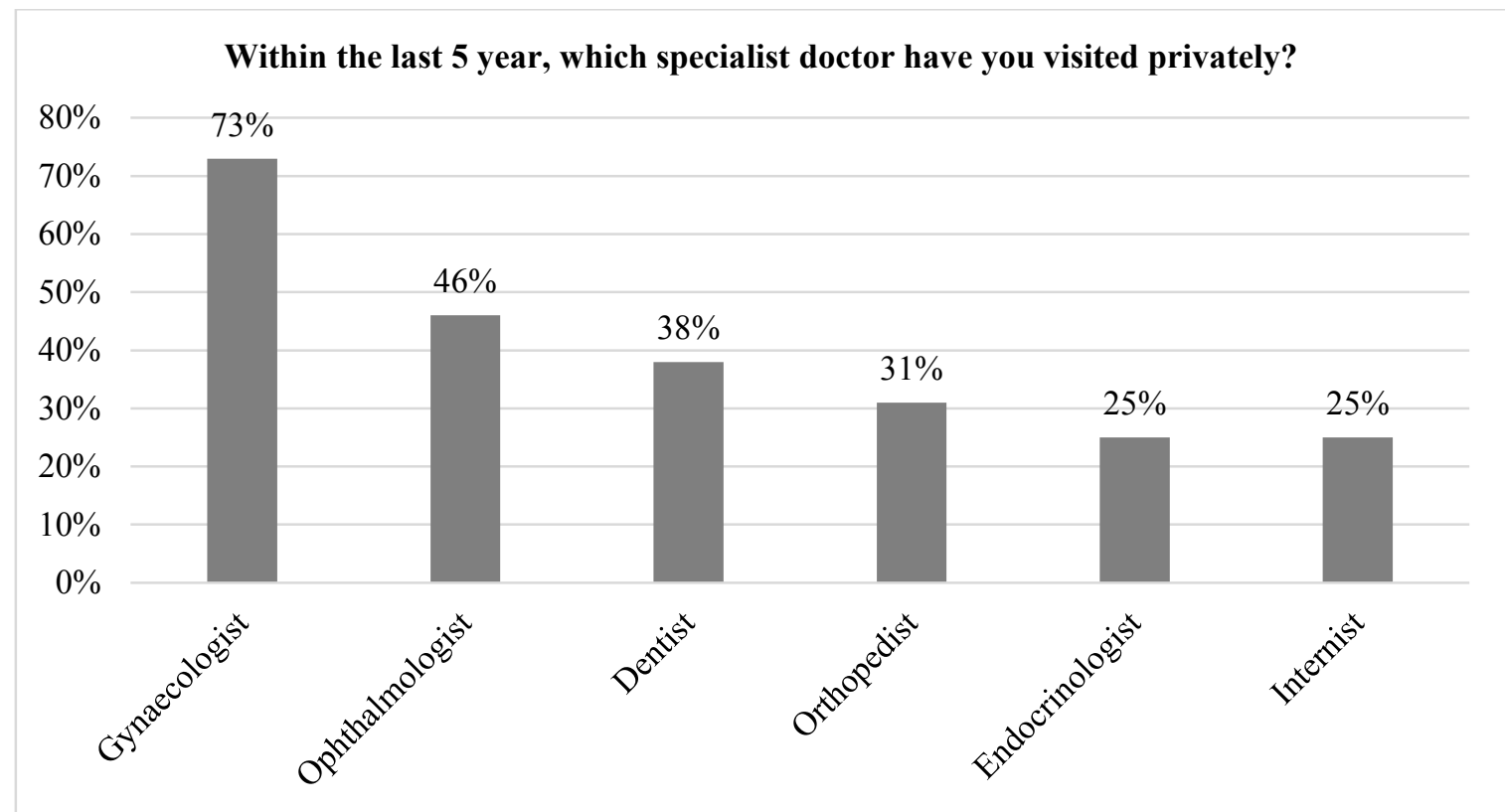

Figure 5. The most common choice of specialists among respondents within last 5 years - women. Source: own study.

The biggest number of women (73\%) indicated a gynecologist as a specialist visited in the last 5 years. Many female respondents also chose ophthalmologist (46\%) and dentist (38\%). A notable number of women chose orthopedist (31\%), which is also frequently indicated by men, and endocrinologist (32\%), which on the other hand is rarely chosen by the male group. Internist's services are prevalent in both women (25\%) and men groups. Results for men are shown below in Figure 7.

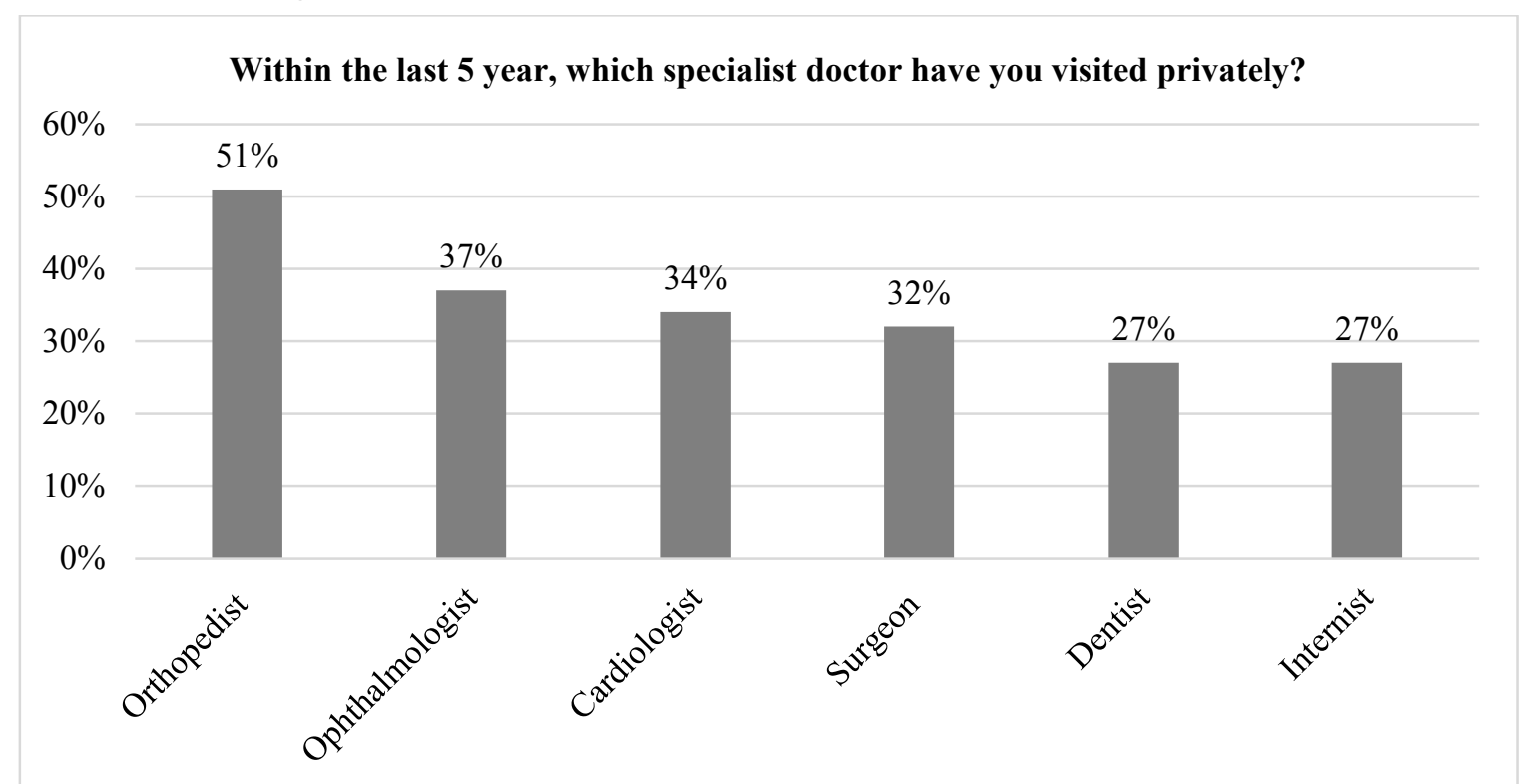

Figure 6. The most common choice of specialists among respondents within last 5 years - men. Source: own study. 
The biggest number of men indicated orthopedist (51\%). The second most attended specialist was ophthalmologist (37\%) in both men and women groups of respondents. Then approximately the same number of men respondents chose cardiologist $(34 \%)$ and surgeon (32\%). The last major group of men indicated dentist (27\%) and internist (27\%) with the same frequency. Moreover, internist was indicated by a similar number of men $(27 \%)$ and women.

\section{Conclusion and recommendations}

Polish health care sector is one of the national economy segments. However, an insufficient number of physicians able to deliver medical services, deficient financial funding and several problems related to waiting time and availability of appointments, support private sector popularization. Moreover, the current situation in public health care system is extremely difficult due to recent SARS-CoV-2019 pandemic burdens. The main purpose of this article was to explore the main factors of choice of private medical services by Polish patients. The answers collected in the survey are not strongly polarized and reveal similar opinions of respondents about factors of private medical services choice in Poland. Over $90 \%$ of respondents indicated that they have used private medical services in Poland in the last 5 years. The largest number of people taking part in the study indicated that they pay for private health services with their own funds. The reason for having to pay for medical services with own funds is probably due to the lack of an alternative in the form of private insurance provided by the employer.

According to MAHTA (2019), the most important problem of public health care system in Poland is limited access to specialists. Based on the results of Watch Health Care Foundation by MAHTA and comparing it to data collected in April and May 2018, accessibility to treatment has even worsened. To obtain specialist advice, one has to wait on average 3.9 months, up to 11.6 months for an appointment with an endocrinologist (Watch Health Care, 2019). During this time, the patient's health condition may deteriorate and treatment modalities may change to more burdensome in consequences. In addition, it is a discomfort and sometimes suffering for the patient, so the decision to choose private health care for the purpose seems justified.

Taking into consideration the choice of availability of appointments, it is worth implementing and developing solutions that make it easier for patients to schedule visits. Platforms that allow appointments to be registered without contacting the registration desk should be a widely available solution. In addition, good organization of the health care entity allows adequate management of appointment times and avoidance of delays. This may be another important factor for patients, so it is worth investing in the competence of staff, so that in the case of unplanned and independent delays they are able to resolve the situation in 
an appropriate manner, without discouraging the customer from continuing to use the services of the facility.

As the private healthcare sector develops and becomes more competitive, maintaining longterm relationships with patients is crucial. Nowadays, Customer Relationship Management forms the basis of an organization's success by putting the customer and their needs at the center (Wroblewska, 2013).

\section{References}

1. Barometr Fundacji Watch Health Care (2019). Raport na temat zmian $w$ dostepności do gwarantowanych świadczeń zdrowotnych $w$ Polsce, 19/15/02/2019. MAHTA Sp. z o.o. Retrieved from: http://www.korektorzdrowia.pl/wp-content/uploads/barometr_whc_xii_i_ 2019 final.pdf, 22.08.2021

2. Bromber, P. (2017). Interesariusze w systemie ochrony zdrowia. Rola państwa. Finanse, Rynki Finansowe, Ubezpieczenia, nr 5(89), cz. 1. doi:10.18276/frfu.2017.89/1-42.

3. Bukowski, H., Pogorzelczyk, K. (2019). Polish Healthcare Sector Overview, evolution and opportunities. Retrieved from: https://www.innowo.org/userfiles/publikacje/Polish\%20 Healthcare\%20Sector.pdf, 31.08.2021.

4. Bukowski, H., Pogorzelczyk, K. (2019). Polish Healthcare Sector. Overview, evaluation and opportunities Retrieved from: https://www.innowo.org/userfiles/publikacje/Polish\%20 Healthcare\%20Sector.pdf, 31.08.2021.

5. Can, G, Isin, F. (2018). Which criteria determine the winner for patient? Journal of Turkish Operations Management. Retrieved from: https://feridebaharisin.com/wp-content/uploads/ 2020/05/5c3792a8b73ce.pdf, 06.08.2021.

6. Garedew, M., Woldie, M., Walle, A. (2019). Choice of Healthcare Providing Facility and Associated Factors among Government Employees in Nekemte Town, Western Part of Ethiopia. Compliance of Nurses to National Nursing Process Guideline in Tercha General Hospital, Southern Ethiopia 2018: Case Study. doi:10.21767/2254-9137.100102.

7. Gołębiowski, P., Wojnarowska, M. Jędrzejczyk, T. (2017). Identyfikacja kluczowych czynników sukcesu w podmiotach leczniczych na przykładzie świadczeń okulistycznych. Zeszyty Naukowe Politechniki Śląskiej - Organizacja i Zarządzanie, z. 114.

8. Guy, M. (2019). Between 'going private' and 'NHS privatisation': Patient choice, competition reforms and the relationship between the NHS and private healthcare in England. Legal Studies, 39(3), 479-498. doi:10.1017/1st.2018.55.

9. Jędrzejczyk, T., Wojtecka, A., Zarzeczna-Baran, M. (2017). Szanse i zagrożenia ze strony sektora publicznego dla strategii rozwoju innowacji podmiotów leczniczych w zakresie 
e-zdrowia i telemedycyny. Zeszyty Naukowe Politechniki Śląskiej - Organizacja i Zarzadzanie, z. 113.

10. Korporowicz, V. (2012). Zarzadzanie systemem ochrony zdrowia. Aspekty ekonomicznospołeczne. Oficyna Wydawnicza Szkoły Głównej w Warszawie.

11. Malik, J., Sharma, V. (2017). Determinants of Patients' Choice of Healthcareprovider a Study of Selected Private Hospitals in Delhi - NCR. NICE Journal of Business, Vol. 12, No. 1, Retrieved from: https://www.researchgate.net/publication/322499131 DETERMINANTS_OF_PATIENTS'_CHOICE_OF_HEALTHCAREPROVIDER_A_Study_of_Selected_Private_Hospitals_in_Delhi-NCR, 05.08.2021.

12. Ministry of Foreign Affairs (2019). Medical Services in Poland Selected Offers for the Middle East Market. Ministry of Foreign Affairs Republic of Poland.

13. OECD (2021). Health spending. Retrieved from: https://data.oecd.org/healthres/healthspending.htm, 19.07.2021.

14. Pietryka, E. (2018). Finansowanie systemu opieki zdrowotnej w Polsce w kontekście wprowadzenia systemu sieci szpitali Finansowanie systemu opieki zdrowotnej w Polsce. Journal of Management and Finance Vol. 16, No. 3/1. Retrieved from https://wzr.ug.edu.pl/.zif/10_14.pdf, 31.08.2021.

15. Rutkowski, E. (2019). Medical devices and equipment industry in Poland. Polish Agency for Enterprise Development. Retrieved from https://www.parp.gov.pl/attachments/ article/55964/KATALOG.pdf, 31.08.2021.

16. Wielicka, K. (2014). Zarys funkcjonowania systemów opieki zdrowotnej w wybranych krajach Unii Europejskiej. Zeszyty Naukowe Politechniki Ślaskiej - Organizacja i Zarzadzanie, z. 70.

17. Wróblewska, W. (2013). Zarządzanie relacjami z klientami jako źródło sukcesu organizacji. Zeszyty Naukowe Uniwersytetu Przyrodniczo-humanistycznego w Siedlcach. Administracja $i$ Zarzadzanie. Retrieved from: https://core.ac.uk/download/pdf/160237291.pdf, 07.09.2021.

18. Zgliczyński, W. (2018). Ochrona zdrowia w Polsce. Wybrane zagadnienia. Wydawnictwo Sejmowe, Infos, Biuro Analiz Sejmowych, 15(253), p. 2. Retrieved from http://orka.sejm.gov.pl/WydBAS.nsf/0/F433A1B0A29A17E6C125836A004BF98C/\$file/I nfos_253.pdf, 31.08.2021. 